\title{
Criminal Law Policy in Combating Land Use Changes that Cause Environmental Problems
}

\author{
Lusy K.F.R. Gerungan ${ }^{1}$, Herlyanty.Y.A.Bawole ${ }^{1}$, Yanti Amelia Lewerissa ${ }^{2 *}$ \\ \{elyanti_amelia@yahoo.com²\}
}

Faculty of Law, Universitas Sam Ratulangi ${ }^{1}$, Faculty of Law, Universitas Pattimura ${ }^{2}$

\begin{abstract}
The rapidly increasing population growth is not accompanied by an adequate amount of land, causing land that should not be designated for settlements to become settlements which in turn causes various environmental problems. The purpose of this study is to analyze criminal law policies in tackling people's behavior towards land conversion which causes environmental problems such as flooding, landslides, garbage and declining quality of clean water. The research method used in this research is normative legal research, the data source used is secondary data obtained through literature study which is then analyzed qualitatively. Based on the results of the study, the social conflict that occurred in Ambon in 1999 led to the division of settlements based on ethnicity, religion, race and inter-group as well as the increasing number of residents while the increasingly narrow land area became a factor causing people to open settlements in areas/land that were not for its purpose. Residential settlements are built in disaster-prone areas such as on the banks of rivers or on the slopes of mountains, residents cut down trees to clear land even though it is a water catchment area and densely populated settlements that are not in accordance with spatial management cause various environmental problems such as floods, landslides, accumulation of garbage and decreased quality of clean water. There is a need for a Criminal Law Policy in overcoming land use changes that can cause complex environmental problems.
\end{abstract}

Keywords: Criminal Law Policy; Changes in Land Function; Environment

\section{Introduction}

The environment is a gift from God Almighty to humans to live and work, including the people of Indonesia. The Indonesian environment is a gift from God to the Indonesian people and is a space for life in all its aspects. In living life in the environment as a gift from God, humans are required to be able to carry out environmental management while preserving and developing harmonious, harmonious, and balanced environmental capabilities in order to support the implementation of sustainable development with an environmental perspective so that the next generation can still exist and enjoy clean and healthy living environment. 
But in reality, sometimes various environmental problems arise that cause a loss of natural balance and can bring disaster to human life. Various studies have been conducted to discuss environmental problems from various aspects, such as what was done by Eko and Rahayu who studied land use changes from the spatial aspect that land use changes are related and their suitability to RDTR in Per-Urban Areas [1] Likewise, the problem of land use change from the economic and spatial aspects was discussed by Pidora and Pigawati about how the relationship between settlement developments and changes in land prices in the Tembalang area [2]. Furthermore, research from the economic and social aspects was carried out by Ante et al, who studied the economic and social impacts of the conversion of horticultural agricultural land into a tourist area of Badan Hills in East Tomohon District, Tomohon City [3].

Meanwhile, from the legal aspect, research on land use changes is also studied from various aspects. As research from the side of law enforcement conducted by Baiq Burdatun [4]. Furthermore, the research from the side of justice conducted by Nurhidayah and Karjoko on the aspect of justice for the conversion of agricultural land to non-agricultural land must pay attention to aspects of its benefits for the surrounding community [5]. Similarly, research from the legal aspect of spatial planning conducted by Amir [6]. In contrast to previous studies, the authors are interested in studying changes in land use that cause various environmental problems in terms of criminal law policies.

Starting from the emergence of social conflict in 1999 in Ambon City, people lived in groups based on ethnicity, religion, race and class. Continuing with the rapid increase in population while not accompanied by land that does not increase in size, causing the community to open residential land that is not for its designation, such as occupying areas along rivers and mountain slopes. This raises complex environmental problems such as floods, landslides, garbage and decreased quality of clean water. For this reason, there is a need for policies that have been made by the Provincial and City Governments related to spatial planning or land functions. Thus, this study will examine criminal law policies in tackling changes in land use that can cause environmental problems.

\section{Research Methods}

This type of research is normative legal research that examines criminal law policies in tackling land use changes that cause environmental problems. According to Fajar ND and Achmad, normative legal research views law as a set of norm systems [7]. Furthermore, the approach used in this research is a statutory approach and a conceptual approach. Sources of data needed in this study is secondary data [8]. The technique of collecting data is through a literature study and then analyzed qualitatively, namely by describing the data through the form of words and used to interpret and interpret oral or written data from people or observed behavior [9].

\section{Literature Review}

\subsection{Land Conversion}


The results of the Population Census (SP2020) in September 2020 recorded a population of 270.20 million people. The population as a result of the SP2020 increased by 32.56 million people compared to the results of the SP2010. With Indonesia's land area of 1.9 million $\mathrm{km} 2$, the population density of Indonesia is 141 people per $\mathrm{km} 2$. The annual population growth rate during 2010-2020 is 1.25 percent on average [10]. The population of Indonesia is increasing from year to year. Even with a population of 276,534,274 people, Indonesia occupies the fourth position in the list of countries with the most population. The population of Indonesia is equivalent to 3.51 percent of the total world population [11]. By looking at these conditions, Indonesia is vulnerable to land conversion to be used as buildings or residences where productive land is used as housing to support the population growth.

According to Lestari, land conversion or also known as land conversion is a change in the function of part or all of the land area from its original function (as planned) to other functions that have a negative impact (problem) on the environment and the potential of the land itself [12]. Meanwhile, according to Kustiawan, land conversion means the transfer of function or mutation of land in general regarding the transformation in the allocation of land resources from one use to another [13]. Supriyadi in Eka Puta and Ismail states that there are at least three important factors that cause the conversion of paddy fields as follows: [14]

a. External factors; is a factor caused by the dynamics of urban growth (physical and spatial), demography and economy.

b. Internal factors; This factor looks more at the side caused by the socio-economic conditions of agricultural households using land.

c. Policy factors; namely various regulations issued related to land conversion

From the various definitions and factors that cause land use change, it can be concluded that land use change is a change in the use or designation of a land due to various factors, both internal and external factors.

\subsection{Criminal Law Policy}

According to Barda Nawawi Arief, there are main things in terms of preventing and overcoming crime, namely: [15]

a. Crime prevention and control must support the goals, community welfare/social welfare and community protection/social defense.

b. Crime prevention and control must be carried out with an integral approach, there is a balance between penal and non-penal means.

c. Prevention and control of crime by means of penal is a penal policy or penal law enforcement policy whose functionalization/operationalization goes through several stages, namely: (1) Formulation stage (legislative policy); (2) Application stage (judicial/judicial policy): (3) Execution stage (executive policy) /administrative)

Crime prevention and control includes law enforcement policies. Law enforcement policies themselves include preventive and repressive measures. Preventive is an effort to prevent violations of the PPLH Law, which can be in the form of negotiation, and supervision or advice or assistance. Meanwhile, repressive law enforcement is an effort to resolve cases, in this case crimes in the environmental field, from the police, prosecutors to court levels [16]. 
According to A.S Alam, crime prevention efforts can be carried out in 3 important parts, namely: the pre-emptive stage, the preventive stage and the repressive stage [17]. Pre-Emtif is the initial action taken by law enforcement (police) in the form of instilling moral values that are expected to be integrated in a person to prevent the occurrence of criminal acts. Prevention is a follow-up to pre-emptive efforts. In the form of action to suppress the opportunity to commit a crime. While repressive is an action taken when a crime occurs, in this case the law enforcement process is running.

\section{Discussion}

\subsection{Environmental Issues in Ambon City}

Ambon City is the capital of Maluku Province. The location of Ambon City is mostly in the Ambon Island area, which geographically is in the position of: $3^{\circ}-4^{\circ}$ South Latitude and $128^{\circ}$ $129^{\circ}$ East Longitude, where in general Ambon City covers the area along the inner coast of Ambon Bay and the outer coast of the Leitimur Peninsula with the total length of the coastline is $102.7 \mathrm{~km}$ [18]. The area of Ambon City is $359.45 \mathrm{~km} 2$ with a population of 427,934 people (2016). In 2016, the highest population density concentration was in Sirimau District with a population of 178,611 people or $41.7 \%$ of the total population of Ambon City. The high population density in Sirimau District is because this district is a downtown area with various trading service activities so that it attracts residents to live and carry out activities in Sirimau District.

The social conflict that occurred in 1999 caused the people of Ambon to live in a patterned manner based on their ethnicity, religion, race and class. Many settlements are built in protected areas such as the Air Besar Forest, Gunung Nona Forest and Mount Sirimau Forest. As has been stated, the concentration of the population is mostly in the Sirimau sub-district. So that there has been a change in land function in Sirimau District, Ambon City in the last decade. This change is very large for residential areas, which is 1036.1 Ha. Land conversion in Sirimau Sub-district leads to the south and east, namely to the coastal and mountainous areas, while the land conversion towards the east is more of a land conversion from forest land and dry agricultural land into residential land [19]. In the span of 2003, 2009, 2015 land use change that occurred in Ambon City was caused by the high demand for residential land [20].

The conversion of land into residential land creates complex environmental problems. Patterned settlements lead to the emergence of new settlements that affect the problem of waste and clean water quality. Likewise, when residential areas are limited, there are some people who are desperate to open residential land in areas prone to natural disasters. Like on mountain slopes and river banks. Even protected areas (water catchment areas) were used as residential land. So that during the rainy season, floods, landslides and piles of garbage everywhere cannot be avoided.

Such as floods and landslides that caused the death of 18 people died, 500 houses were damaged, and thousands of houses were submerged in water, and hundreds of vehicles were swept away by the floodwaters, when flash floods hit Ambon City on Wednesday, August 1, 2012. flash floods, such as the village of Batu Merah, the Air Besar area and the Ambon State Islamic Institute (IAIN), the military dormitory of Batu Merah, Amantelu Village, Kadewatan, Batu Gajah, Batu 
Meja, Ponegoro, Waihaeng, Silale, Soabali, Pule Tree, Water Matacina, Parigilima, and Jalan Baru Ambon [21]. The areas above are densely populated residential areas and riverbank areas. These disasters have been repeated every year in recent years, resulting in property losses and loss of life.

The conversion of land into residential land creates complex environmental problems. Patterned settlements lead to the emergence of new settlements that affect the problem of waste and clean water quality. Likewise, when residential areas are limited, there are some people who are desperate to open residential land in areas prone to natural disasters. Like on mountain slopes and river banks. Even protected areas (water catchment areas) were used as residential land. So that during the rainy season, floods, landslides and piles of garbage everywhere cannot be avoided.

Such as floods and landslides that caused the death of 18 people died, 500 houses were damaged, and thousands of houses were submerged in water, and hundreds of vehicles were swept away by the floodwaters, when flash floods hit Ambon City on Wednesday, August 1, 2012. flash floods, such as the village of Batu Merah, the Air Besar area and the Ambon State Islamic Institute (IAIN), the military dormitory of Batu Merah, Amantelu Village, Kadewatan, Batu Gajah, Batu Meja, Ponegoro, Waihaeng, Silale, Soabali, Pule Tree, Water Matacina, Parigilima, and Jalan Baru Ambon[21]. The areas above are densely populated residential areas and riverbank areas. These disasters have been repeated every year in recent years, resulting in property losses and loss of life.

\subsection{Criminal Law Policies in Tackling Changes in Land Functions}

As previously explained, it turns out that the conversion of land functions, whether from dry agricultural land, protected forest land or land / areas prone to disasters as residential areas, can cause environmental problems such as piles of garbage, floods, landslides, decreased water quality and even slum settlements. in Ambon City. A criminal law policy is needed in dealing with land conversion for residential areas so that it can prevent environmental problems that can bring disaster to us.

In Law no. 32 of 2009 concerning Environmental Protection and Management (hereinafter abbreviated as UUPPLH), there is no formulation of an article that specifically regulates the conversion of land functions that can cause environmental problems. However, in Article 69 paragraph (1) letter a it is stated that: "Everyone is prohibited from committing acts that result in pollution and/or damage to the environment"

There are no criminal provisions governing the prohibited acts as referred to in Article 69 paragraph (1) letter a. Then in Chapter XV concerning Criminal Provisions, Article 98 paragraph (1) states that: "Everyone who intentionally commits an act that results in exceeding the ambient air quality standard, water quality standard, sea water quality standard, or environmental damage standard criteria, shall be punished with imprisonment for a minimum of 3 (three) years and a maximum of 10 (ten) years. years and a minimum fine of Rp.3,000,000,000.00 (three billion rupiah) and a maximum of Rp.10,000,000,000.00 (ten billion rupiah)."

Furthermore, Article 109 to Article 112 regulates criminal acts related to Licensing and Supervision. Furthermore, if an environmental crime is committed by a legal entity (corporation) it is regulated in Articles 116 to 118 . Article 119 provides for additional criminal/disciplinary actions for legal entities. Overall, the use of criminal sanctions in UUPPLH for imprisonment for a minimum of 1 year and a maximum of 12 years in prison. Meanwhile, a minimum fine of $\mathrm{Rp}$. 
$500,000,000$ (five hundred million rupiah) and a maximum fine of Rp. 12,000,000,000 (twelve billion rupiah).

The use of criminal sanctions as an ultimum remedium to strengthen the operation of UUPPLH as administrative criminal law. UUPPLH tends to be seen as a law that prioritizes repressive aspects (in this case the use of criminal sanctions) instead of environmental management that prioritizes preventive aspects [22]. This is proven by the absence of a deterrent effect for perpetrators of environmental crimes.

Whereas in Chapter IX which also regulates community participation in environmental protection and management, it can be optimized as a non-penal policy (policies that do not use criminal law) in addition to administrative sanctions and civil sanctions in tackling land conversion activities for residential areas that can lead to environmental issues. Likewise, optimizing the role of local governments in making regional regulations that can be used as a legal basis for overcoming land conversion for residential areas.

Likewise, there is Law Number 26 of 2007 concerning Spatial Planning, which the implementation of its authority is carried out by the central and regional governments while respecting the rights of every person. The existence of the Spatial Planning Law with its derivatives in the form of spatial planning is an important effort in controlling the implementation of spatial planning in Indonesia which is realized through several important aspects, one of which is controlling the use of space. Control of space utilization is carried out systematically through the stipulation of zoning regulations, permits, incentives and disincentives, and sanctions. Spatial planning activities consist of 3 (three) interrelated activities, namely: spatial planning, space utilization, and space utilization control, with the product of a spatial plan in the form of a Regional Spatial Plan (RTRW) which hierarchically consists of a Regional Spatial Plan. National Spatial Planning (RTRWN), Provincial Spatial Planning (RTRWP), and Regency/City Spatial Planning (Regency/City RTRW) [23]. With a well-organized spatial arrangement, especially in the Ambon City area and its surroundings, it can minimize and even prevent the emergence of residential areas that are not built on the designated land so as not to bring complex environmental problems.

\section{Conclusion and Suggestion}

\subsection{Conclusion}

Based on the description described above, it can be concluded that the conversion of land that is not intended for residential use can cause very complex environmental problems. Such as floods, landslides, decreased water seedlings, decreased quality of clean water and waste problems. This environmental problem can cause property loss and even loss of human life. there needs to be a criminal law policy that can overcome the occurrence of land conversion that is not intended for residential areas.

\subsection{Suggestion}


It is necessary to optimize and empower the participation of the community, especially the awareness of the community itself as well as the role of local governments (through the making of a regional regulation that regulates the prohibition of land conversion and spatial planning).

\section{References}

[1] T. Eko and S. Rahayu, "Land use change and suitability for RDTR in peri-urban areas. Case Study: District Mlati," J. Pembang. Wil. dan Kota, vol. 8, no. 4, pp. 330-340, 2012.

[2] D. Pidora and B. Pigawati, "Keterkaitan Perkembangan Permukiman dan Perubahan Harga Lahan di Kawasan Tembalang," J. Wil. dan Lingkung., vol. 2, no. 1, p. 1, 2014, doi: 10.14710/jwl.2.1.1-10.

[3] E. Ante, N. M. Benu, and V. R. . Moniaga, "Dampak Ekonomi dan Sosial Alih Fungsi Lahan Hortikultura Menjadi Kawasan Wisata Bukit Rurukan di Tomohon Timur, Kota Tomohon," J. Agri-SosioEkonomi Unsrat, vol. 12, no. 3, pp. 113-124, 2016, [Online]. Available: file:///C:/Users/user/Downloads/75279-ID-dampak-ekonomi-dan-sosial-alihfungsi-la.pdf.

[4] B. Burdatun, "Penegakan Hukum Terhadap Alih Fungsi Lahan Pertanian Menjadi Lahan Non Pertanian Di Kota Mataram Law Enforcement on Conversion of Agricultural Land To Other Uses in Mataram," J. IUS Kaji. Huk. dan Keadilan, vol. 4, no. 3, pp. 452-466, 2016, doi: http://dx.doi.org/10.29303/ius.v4i3.370.

[5] Z. T. Nurhidayah and L. Karjoko, "Alih Fungsi Lahan Pertanian Ke Non Pertanian (Studi Kecamatan Nguter Kabupaten Sukoharjo ),” J. Repert., vol. IV, no. 2, pp. 152-159, 2017.

[6] N. Amir, "Aspek Hukum Pengaturan Tata Ruang Terhadap Alih Fungsi Lahan Dalam Rangka Pembangunan Nasional," J. Justiciabelen, vol. 1, no. 1, p. 120, 2018, doi: 10.30587/justiciabelen.v1i1.497.

[7] M. Fajar and Y. Achmad, Dualisme Penelitian Hukum Normatif dan Empiris. Yogyakarta: Pustaka Pelajar, 2010.

[8] P. M. Marzuki, Legal Research, 9th Printi. Jakarta: Kencana, 2016.

[9] L. J. Moleong, Metodologi Penelitian Kualitatif. Bandung: Rosda Karya, 1991.

[10] Badan Pusat Statistik, "Hasil Sensus Penduduk 2020." https://www.bps.go.id/pressrelease/2021/01/21/1854/hasil-sensus-penduk-2020.html.

[11] A. P. Kasih, "5 Negara dengan Populasi Terbanyak di Dunia, Indonesia Nomor Berapa?," Kompas.com, 2021. https://www.kompas.com/edu/read/2021/07/30/113751971/5-negaradengan-populasi-terbanyak-di-dunia-indonesia-nomor-berapa?page=all.

[12] T. Lestari, "Dampak Konversi Lahan Pertanian Bagi Taraf Hidup Petani," Institut Pertanian Bogor, 2009.

[13] I. Kustiawan, "Konversi Lahan Pertanian di Pantai Utara Pulau Jawa," Prisma, vol. 1, 1997.

[14] D. Eka Putra, A. Muhammad Ismail, M. Agribisnis, and P. Negeri Jember Jln Mastrip Kotak Pos, "Faktor-Faktor Yang Mempengaruhi Petani Dalam Melakukan Alih Fungsi Lahan Di Kabupaten Jember," Agritech, vol. XIX, no. 2, pp. 99-109, 2017.

[15] B. N. Aried, Masalah Penegakan Hukum dan Kebijakan Hukum Pidana dalam Pemberantasan Kejahatan. Jakarta: Kencana, 2007. 
[16] D. A. S. Dewi, "KONSEP PENGELOLAAN LINGKUNGAN HIDUP MENUJU KEMAKMURAN MASYARAKAT," J. Fak. Huk. Univ. Muhammadiyah Magelang, vol. 1, no. 1, 2021.

[17] A. S. Alam, Pengantar Kriminologi. Makassar: Pustaka Refleksi Books, 2010.

[18] “Website Pemkot Ambon.” https://ambon.go.id/.

[19] B. M. Laka, U. Sideng, and A. -, "Perubahan Penggunaan Lahan Di Kecamatan Sirimau Kota Ambon," J. Geocelebes, vol. 1, no. 2, p. 43, 2017, doi: 10.20956/geocelebes.v1i2.2165.

[20] E. F. Metekohy et al., "PERUBAHAN TATA GUNA LAHAN PADA PUSAT KOTA AMBON," Spasial (Perencanaan Wil. dan Kota), vol. 3, no. 1, 2016, [Online]. Available: https://ejournal.unsrat.ac.id/index.php/spasial/article/view/12022/11611.

[21] M. Touwe, "Korban Banjir Ambon Bertambah Menjadi 18 Orang," Tempo.com, 2012. https://nasional.tempo.co/read/420939/korban-gunung-ambon-bercepat-jadi-18-orang.

[22] S. S. Rangkuti, Hukum Lingkungan dan Kebijaksanaan Lingkungan Nasional. Surabaya: Airlangga University Press, 2000.

[23] Kemenhukumdanham, "Laporan akhir tim pengkajian hukum tentang penegakan hukum penataan ruang dalam kerangka otonomi daerah," p. 135, 2014. 